\title{
Kinetic modeling of organic and nitrogen removal from domestic wastewater in a down-flow hanging sponge bioreactor
}

\author{
Dinh Thi $\mathrm{Nga}^{{ }^{\dagger}}$, Nguyen Trung Hiep ${ }^{2}$, Nguyen Tri Quang Hung ${ }^{2}$ \\ ${ }^{1}$ Research Institute for Sustainable Development, Hochiminh City University of Natural Resources and Environment, Tan Binh District, Hochiminh \\ City, Vietnam \\ ${ }^{2}$ Faculty of Environment and Natural Resources, Nong Lam University - Hochiminh City, Thu Duc District, Hochiminh City, Vietnam
}

\begin{abstract}
A down-flow hanging sponge (DHS) bioreactor was operated for the treatment of domestic wastewater. The Stover-Kincannon model was applied for kinetic evaluation of the reactor performance during the operational period. As a result, the coefficient of determination $\left(R^{2}\right)$ for straight lines of effluent concentration from the experimental data and from the predictive data of $\mathrm{BOD}_{5} ; \mathrm{NH}_{4}{ }^{+}-\mathrm{N}$; and $\mathrm{TN}$ were 0.9727 ; 0.9883 ; and 0.9934 , respectively. The calculation of saturation value constant (Umax $-\mathrm{g} \mathrm{L}^{-1} \mathrm{~d}^{-1}$ ) and maximum utilization rate constant (KB - g L-1 d-1) were 56.818 and 75.034 for $\mathrm{BOD}_{5} ; 2.960$ and 4.713 for $\mathrm{NH}_{4}{ }^{+} \mathrm{N}$; 2.810 and 8.37 for TN, respectively. The study suggests that Stover-Kincannon model can be used for effective evaluation of kinetic removal of $\mathrm{BOD}_{5} ; \mathrm{NH}_{4}{ }^{+}-\mathrm{N}$; and $\mathrm{TN}$ from domestic wastewater treated in a DHS bioreactor.
\end{abstract}

Keywords: Domestic wastewater, Down-flow hanging sponge, Kinetic modelling, Removal efficiency, Stover-Kincannon model

\section{Introduction}

In recent years, environmental pollution is one of the most serious challenges due to the population boom, industrialization, and urbanization [1-4]. Going together with industrial activities many toxic compounds have been discharged into the environment and have created negative impacts on public health and environment. Therefore, developing technologies for removing contaminants from wastewater has attracted remarkable attention in the world [5-7].

Biological treatment is the prior process to remove organic matters and nutrients in wastewater [8]. In bioreactors, microorganisms perform in two behaviors which are attached growth and suspended growth. In the attached growth process, microorganisms attach to the support materials to form biofilms [9]. The DHS reactor is one application of attached process which has many advantages such as high organic loading rate, high removal efficiency, long sludge retention time, short hydraulic retention time [1, 10-12]. Therefore, many authors have been investigated this model in treating different types of wastewater [11, 13-16]. Mahmoud et al. [11] applied a hybrid up-flow anaerobic sludge blanket reactor and a DHS reactor to treat domestic wastewater. They found out that this system could gain the removal values of $\mathrm{COD}_{\text {total }}, \mathrm{COD}_{\text {soluble, }}$ BOD $_{5 \text { total, }}$ TSS and TN were $90 \pm 4,78 \pm 8,95 \pm 2,96 \pm 5$ and $72 \pm 8 \%$, respectively.

In addition, the DHS model was good at organic matter and nitrogen removal with OLR up to $4.8 \mathrm{kgCOD} \mathrm{m}^{-3} \mathrm{~d}^{-1}$ [11]. Tawfik et al. [13] operated DHS system treating UASB reactor effluent, they demonstrated that when increasing the retention time from 1.0 to $6.0 \mathrm{~h}$, sponge bulk volume from 12.9 to 51.6 liter, and decreasing sponge pored size from 1.92 to $0.56 \mathrm{~mm}$ the removal of fecal coliform was improved. Fleifle and colleagues researched on modeling and profile analysis of a DHS system treating agricultural wastewater with the hydraulic retention time of $2 \mathrm{~h}$ and organic loading rate of $3 \mathrm{~kg} \mathrm{COD} \mathrm{m} \mathrm{m}^{-3} \mathrm{~d}^{-1}$. Results showed that the average removal was $83.7 \%$ for $\mathrm{COD}_{\text {total }}, 88.6 \%$ for $\mathrm{COD}_{\text {soluble, }}$, $66.7 \%$ for TKN, $85.0 \%$ for $\mathrm{NH}_{4}{ }^{+}-\mathrm{N}$, and $88.9 \%$ for TSS [14]. In another investigation, DHS model was applied to treat low strength sewage at HRT of $1.5 \mathrm{~h}$ the reactor achieved the removal efficiency of TSS, BOD and Coliform at 90\%; 85\%; 98\%, respectively without external aeration energy [16]. Nomoto et al. [15] studied on the performance of DHS with four layers, they demonstrated that half
This is an Open Access article distributed under the terms of the Creative Commons Attribution Non-Commercial License (http://creativecommons.org/licenses/by-nc/3.0/) which permits unrestricted non-commercial use, distribution, and reproduction in any medium, provided the original work is properly cited.

Copyright (C) 2020 Korean Society of Environmental Engineers
Received November 5, 2018 Accepted March 23, 2019

${ }^{\dagger}$ Corresponding author

Email: dtnga@hcmunre.edu.vn

Tel: +84-979-902-124

ORCID: 0000-0002-9996-0102 
of the COD was removed by the first layer, organic removal followed the first order reaction equation from the second to the fourth layers. When increasing the hydraulic retention time, the removal of $\mathrm{NH}_{4}{ }^{+}-\mathrm{N}$ was improved [15]. These studies indicated the potential of applying DHS system in wastewater treatment. Thus, it needs to be investigated deeply in term of changing type of wastewater, operated conditions as long as kinetic modeling to make full understanding and wide application in environmental engineering.

Kinetic models have been applied to determine the trend of substrate utilization rates. These are principally nonlinear and the nonlinear regression approach is applied for calculation of kinetic constant values [17]. By using kinetic models, the experimental results can be used for estimating the performance of similar processes in the similar operational conditions [18, 19]. An understanding of the process kinetics provides a judicious basis for the design, prediction, development, and operation of processes [20-22]. Kinetic models have presently used in environmental engineering for designing and optimizing the wastewater treatment. Especially, many kinetic models have developed to investigate the biodegradation of wastewater in both anaerobic processes [23, 24] and aerobic processes [25-29]. Many kinetic models have been studied to determine the substrate removal rate in wastewater treatment such as First-order, Grau second-order, Monod and Stover-Kincannon [17, 18, 20]. The Stover-Kincannon model was developed by Kincannon and Stover to designate the relationship between substrate utilization rate and organic loading rate for a biofilm reactor [30]. The performance of a bioreactor can be predicted base on the kinetic constants found out from this model such as maximum utilization rate $\left(\mathrm{U}_{\max }\right)$ and saturation value $\left(\mathrm{K}_{\mathrm{B}}\right)$. Therefore, the StoverKincannon model has been commonly applied to describe carbonaceous removal of organic matters and nutrients in wastewater treatment [17-19, 31]. However, there is limited research that refers to the determination of biodegradation kinetic constants for attached growth process of the aerobic attached growth in DHS model treating domestic wastewater. Therefore, this paper presents an analytical approach of using the Stover-Kincannon model for removing of BOD, $\mathrm{NH}_{4}{ }^{+}-\mathrm{N}$ and TN a DHS reactor.

\section{Materials and Methods}

\subsection{Reactor Structure and Wastewater Source}

A down-flow hanging sponge bioreactor had capacity of $60 \mathrm{~L}$ and made by polyvinyl chloride (PVC) was operated at ambient condition. The dimensions of DHS system were $1.5 \mathrm{~m}$ in height and $0.2 \mathrm{~m}$ in width of the internal surface. The DHS module column consisted of three identical segments connected vertically in series. Air windows were located between segments for air diffusion. Each segment was filled with polyurethane Bio-Bact spheres $(30 \%(\mathrm{~V} / \mathrm{V})$ of the segment volume). Each polyurethane Bio-Bact sphere had $36 \mathrm{~mm}$ diameter and contains sponge at the core. This structure could avoid the clogging and enhancing air diffusion into the sponge. The schematic diagram of the experimental set up is presented in Fig.1. The total area of sponge and polyurethane sphere had a surface area at $3,300 \mathrm{~m}^{2} \mathrm{~m}^{-3}$, a density at $150 \mathrm{~kg} \mathrm{~m}^{-3}$, a void ratio at 90\% [32].

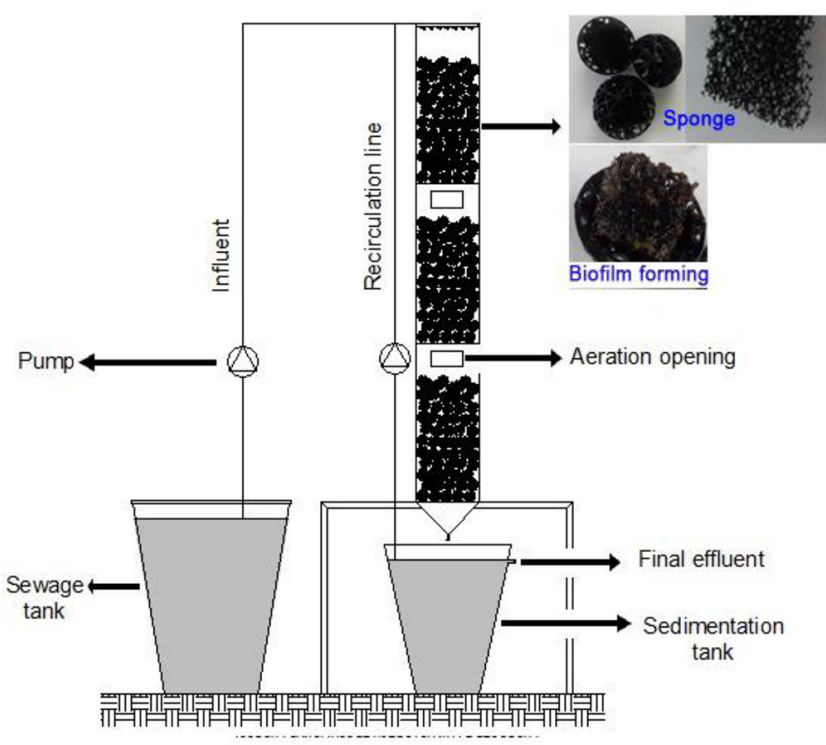

Fig. 1. The schematic diagram of a DHS bioreactor.

The raw wastewater was collected from the storage tank of wastewater discharged from dormitory of a university. Before injecting to the reactor, wastewater was pumped into a container for primary settling of suspended solid matter. The quality of influent wastewater to the reactor for $\mathrm{BOD}_{5} ; \mathrm{NH}_{4}{ }^{+}-\mathrm{N}$; $\mathrm{TN}$ was in the range of $154 \pm 20\left(\mathrm{mg} \mathrm{L}^{-1}\right) ; 40 \pm 20\left(\mathrm{mg} \mathrm{L}^{-1}\right) ; 45 \pm 10\left(\mathrm{mg} \mathrm{L}^{-1}\right)$, respectively.

\subsection{Biofilm Forming and Acclimation}

In this study, activated sludge from the secondary settling tank of a municipal wastewater treatment plant was used to be seed sludge for forming biofilm in the Bio-Bact spheres of DHS reactor. The seed sludge was diluted with tap water to achieve mix liquor suspended solids (MLSS) as at 3,000 $\mathrm{mg} \mathrm{L}^{-1}$. This sludge solution was pumped and recycled continuously through the segments of the DHS system to create the biofilms on the sponge and spheres. After that, dormitory wastewater was injected at low organic loading rate as $0.2 \mathrm{kgCOD} \mathrm{m}^{-3} \mathrm{~d}^{-1}$ for acclimation. This stage was done when the effluent quality was stable and biofilms were uniform in the material.

\subsection{Reactor Operation and Analytical Methods}

After forming biofilms, the experiment was started. During the experiment, wastewater was injected into the top of the DHS model and passed through a distributor and flowed into the segments by gravity and collected at sedimentation tank. Three phases of the experiment were operated in this study corresponding to three levels of organic loading rate as $0.5 ; 1$ and $1.5\left(\mathrm{~kg} \mathrm{COD} \mathrm{m}^{-3}\right.$ day $\left.^{-1}\right)$, each level of organic loading rate levels was operated in 20-30 $\mathrm{d}$ with sampling duration was $81 \mathrm{~d}$. The flow rate was adjusted daily to keep the design organic loading rate depending on organic concentration in the influent. The circular ratio was maintained at 1:1 enhance hydraulic retention time and removal efficiency. Samples of the influent and effluent were taken three times per week and analyzed such parameter $\mathrm{pH}, \mathrm{DO}, \mathrm{BOD}_{5}, \mathrm{COD}, \mathrm{NO}_{3}{ }^{-} \mathrm{N}$ 
$\mathrm{NH}_{4}{ }^{+}-\mathrm{N}$, TN, to evaluate the performance of the reactor. Such parameters $\mathrm{COD}, \mathrm{NO}_{3}{ }^{-} \mathrm{N}, \mathrm{NH}_{4}{ }^{+}-\mathrm{N}$, TN, TP were analyzed in the laboratory according to APHA [33]. Biochemical oxygen demand was analyzed by using BOD-OxiDirect (AL606) AQUALYTIC, Germany [34, 35]. Other parameters such as DO, pH, and turbidity were directly tested by a Multi-Parameter Water Quality Meter, WQC-22A (Japan) [32].

\subsection{Kinetic Modeling}

Kinetic modeling is a significant analytical method for prediction of reactor performance. The Stover-Kincannon model considers the substance removal rate as a function of organic loading rate at steady state as in forms of Eq. (1) and Eq. (2) below [20]:

$$
\begin{gathered}
\frac{d S}{d t}=\frac{Q}{V}\left(S_{i}-S_{e}\right) \\
\frac{d S}{d t}=\frac{U_{\mathrm{max}}\left(Q S_{i} / V\right)}{K_{B}+\left(Q S_{i} / V\right)}
\end{gathered}
$$

where $\mathrm{ds} / \mathrm{dt}$ is the substrate removal rate (g/L-day), $\mathrm{U}_{\max }$ is the maximum utilization rate constant $\left(\mathrm{g} \mathrm{L}^{-1}\right.$ day $\left.^{-1}\right), \mathrm{K}_{\mathrm{B}}$ is the saturation value constant $\left(\mathrm{g} \mathrm{L}^{-1} \mathrm{day}^{-1}\right), \mathrm{Q}$ is the flow rate $\left(\mathrm{L} \mathrm{day}^{-1}\right)$, and $\mathrm{V}$ is the effective volume of the reactor $(\mathrm{L})$

The modification of Eq. (1) and Eq. (2) by in inversing of the substrate removal rate resulting the in-linearization form Eq. (3) followed:

$$
\frac{d S}{d t}=\frac{V}{Q\left(S_{i}-S_{e}\right)}=\frac{K_{B}}{U_{\max }} \times \frac{V}{Q S_{i}}+\frac{1}{U_{\max }}
$$

In this equation, $\mathrm{V} /\left[\mathrm{Q}\left(\mathrm{S}_{\mathrm{i}}-\mathrm{S}_{\mathrm{e}}\right)\right]$ and an inverse of the total loading rate $\mathrm{V} /\left(\mathrm{QS}_{0}\right)$ the linear relationship. This straight line has intercept as $1 / \mathrm{U}_{\max }$ and slope as $\mathrm{K}_{\mathrm{B}} / \mathrm{U}_{\max }$.

After achieving the kinetic constants $U_{\max }$ and $K_{B}$ from the straight line of $\mathrm{V} /\left[\mathrm{Q}\left(\mathrm{S}_{0}-\mathrm{S}_{\mathrm{e}}\right)\right]$ versus $\mathrm{V} /\left(\mathrm{QS}_{0}\right)$ above and the reformation of Eq. (3), the effluent substrate concentration can be calculated at Eq. (4) below when organic loading rate and influent substrate concentration are given.

$$
S_{e}=S_{i} \frac{U_{\max } S_{i}}{K_{B}+\left(Q S_{i} / V\right)}
$$

In this research, the Stover-Kincannon model was applied for the kinetic study of $\mathrm{BOD}_{5} ; \mathrm{NH}_{4}{ }^{+}-\mathrm{N}$; TN profile during the time course. From the experimental result, by applying this model, kinetic constants $\mathrm{U}_{\max }$ and $\mathrm{K}_{\mathrm{B}}$ for those parameters were determined. This result was used to predict the effluent concentration and removal efficiency of $\mathrm{BOD}_{5} ; \mathrm{NH}_{4}{ }^{+}-\mathrm{N}$; TN.

\section{Results and Discussion}

\subsection{Performance Evaluation Results of Operational Parameters}

After the acclimation, the experiment was conducted in $81 \mathrm{~d}$ in which organic loading rate was increased stepwise from 0.5 to $1.5 \mathrm{kgCOD} \mathrm{m}^{-3}$ day $^{-1}$ by adjusting the circulation ratio and decreas- ing hydraulic retention time. Table 2 summaries the performance results of operational parameters. The detail of reactor performance was described in our previous paper [31]. During the operational period, the $\mathrm{pH}$ was stable in the range of 7.0-7.3, this $\mathrm{pH}$ was suitable for the growth of microorganisms in bio-digester. The concentration of DO in the influent was slightly higher than that of effluent. Perhaps, the circulation of the effluent could enhance the diffusion of oxygen from the atmosphere to the DHS reactor segments. During the duration of reactor operation, the influent characteristic was affected by dormitory policy. From d 1-40, cooking was prohibited at the room therefore wastewater was almost from their personal cleaning such as bathing and washing, $\mathrm{BOD}_{5}$ concentration in this phase was in range $34-58 \mathrm{mg} \mathrm{L}^{-1}$. From day 41, many students graduated and moved out; the university allowed to cook inside the dormitory thus $\mathrm{BOD}_{5}$ was remarkably increased in this phase (135-151 mg L ${ }^{-1}$ ) even COD was not much changed. Hence, the ratio of BOD/COD was significantly increased in the later phase. The average COD concentration in the influent and effluent was $279.58 \mathrm{mg} \mathrm{L}^{-1}$ and $78.95 \mathrm{mg} \mathrm{L}^{-1}$, respectively. The maximum $\mathrm{COD}$ and $\mathrm{BOD}_{5}$ removal efficiency was $80 \%$ and 82.8 $\%$, respectively. In previous studies, many authors operated bio-digesters for treatment of wastewater and showed their achieved results. Javid and colleagues operated MBBR for municipal wastewater treatment and achieved average $\mathrm{BOD}_{5}$ removal efficiency of $88 \%$ [8]. In another study, the treatment of sugar industry wastewater treatment by using moving-bed biofilm sequencing batch reactor was investigated and found out the $\mathrm{BOD}_{5}$ and $\mathrm{COD}$ removal efficiencies were obtained to be $85 \%$ and $79 \%$, respectively [19]. The removal efficiency of COD and $\mathrm{BOD}_{5}$ in those authors was higher than that in the present study. It is illustrated that the different of reactor structure, wastewater type, operational conditions effected on experimental results. The average concentration of $\mathrm{NH}_{4}{ }^{+}-\mathrm{N}$ in the influent was varied in range $31.3-63.8 \mathrm{mg} \mathrm{L}^{-1}$; the average removal efficiency of ammonia nitrogen was $60 \%$. Yang and colleagues operated biofilm reactor treating raw water obtained from eutrophicated water bodies with the influent $\mathrm{NH}_{4}{ }^{+}-\mathrm{N}$ in the range of $0.36-3.91 \mathrm{mg} \mathrm{L}^{-1}$, the average effluent $\mathrm{NH}_{4}{ }^{+}-\mathrm{N}$ concentration was at $0.31 \pm 0.09 \mathrm{mg} \mathrm{L}^{-1}$, the removal efficiency of $84.0 \pm 8.1 \%$ [36]. Perhaps, the lower of $\mathrm{NH}_{4}{ }^{+}-\mathrm{N}$ concentration in the influent and the different operational conditions resulting in higher removal ammonium nitrogen compare to the recent study. Nitrate concentration in the influent was illegible; however, its concentration in the effluent was increased in all loading rate (7.3-9.0 $\mathrm{mg} \mathrm{L}^{-1}$ ), and this result indicated the nitrification process performed well in the reactor. The average of total nitrogen removal in this study was about $50 \%$, which is not high. It can be explained that the nitrogen in the influent underwent the reactor only change the form throughout the nitrification process some parts of nitrogen were used for forming biomass of microorganisms in the assimilation process. Based on the structure of reactor and operational conditions, it can be consider that the main mechanisms of organic and nitrogen removal in this research was by aerobic conversion. Organic matters in different forms were underwent assimilation and catabolism. As results, those compounds from wastewater were mainly converted to biomass, carbon dioxide; the untreated portion was presented in the effluent. Ammonia nitrogen was converted to nitrite and then nitrate through the nitrification process. 
Table 1. Summary of the DHS Bioreactor Performance at Different Organic Loading Rates

\begin{tabular}{|c|c|c|c|c|c|c|c|c|c|}
\hline \multirow{2}{*}{ Parameter } & \multicolumn{3}{|c|}{$\begin{array}{c}\text { OLR }_{1} \\
0.5 \mathrm{kgCOD} \mathrm{m}^{-3} \text { day }^{-1}\end{array}$} & \multicolumn{3}{|c|}{$\begin{array}{c}\text { OLR }_{2} \\
1 \mathrm{kgCOD} \mathrm{m}^{-3} \text { day }^{-1}\end{array}$} & \multicolumn{3}{|c|}{$\begin{array}{c}\text { OLR }_{3} \\
1.5 \mathrm{kgCOD} \mathrm{m}^{-3} \text { day }^{-1}\end{array}$} \\
\hline & Influent & Effluent & $\begin{array}{c}\text { Removal } \\
\text { efficiency (\%) }\end{array}$ & Influent & Effluent & $\begin{array}{c}\text { Removal } \\
\text { efficiency (\%) }\end{array}$ & Influent & Effluent & $\begin{array}{c}\text { Removal } \\
\text { efficiency (\%) }\end{array}$ \\
\hline $\mathrm{pH}$ & $7.3 \pm 0.2$ & $7.0 \pm 0.2$ & - & $7.2 \pm 0.2$ & $7.1 \pm 0.2$ & - & $7.3 \pm 0.1$ & $7.1 \pm 0.1$ & - \\
\hline $\begin{array}{l}\text { COD } \\
\left(\mathrm{mg} \mathrm{L}^{-1}\right)\end{array}$ & $276.8 \pm 52.6$ & $73.3 \pm 19.2$ & $72.1 \pm 11$ & $289.2 \pm 37.2$ & $64.5 \pm 3.2$ & $77.4 \pm 2.2$ & $275.4 \pm 55.4$ & $91.2 \pm 28.7$ & $67.2 \pm 7.1$ \\
\hline $\begin{array}{l}\mathrm{BOD}_{5} \\
\left(\mathrm{mg} \mathrm{L}^{-1}\right)\end{array}$ & $50.7 \pm 9.2$ & $11.2 \pm 1.3$ & $77.4 \pm 4.2$ & $72.8 \pm 38.3$ & $18.7 \pm 15.4$ & $76.4 \pm 4.7$ & $141.4 \pm 4.5$ & $41.8 \pm 4.2$ & $70.5 \pm 2.3$ \\
\hline $\begin{array}{l}\text { TSS } \\
\left(\mathrm{mg} \mathrm{L}^{-1}\right)\end{array}$ & $40 \pm 10$ & $20 \pm 10$ & $43.4 \pm 17.7$ & $50 \pm 10$ & $20 \pm 10$ & $62 \pm 13.2$ & $60 \pm 10$ & $20 \pm 10$ & $62 \pm 13.2$ \\
\hline $\begin{array}{l}\mathrm{NH}_{4+}{ }^{-} \mathrm{N} \\
\left(\mathrm{mg} \mathrm{L}^{-1}\right)\end{array}$ & $51.4 \pm 18.8$ & $19.7 \pm 7.2$ & $61.6 \pm 0.5$ & $31.3 \pm 1.3$ & $12 \pm 0.9$ & $61.6 \pm 1.3$ & $63.8 \pm 5.9$ & $27.2 \pm 2.1$ & $57.2 \pm 1.6$ \\
\hline $\begin{array}{l}\mathrm{NO}_{3}^{-} \\
\left(\mathrm{mg} \mathrm{L}^{-1}\right)\end{array}$ & $0.2 \pm 0.1$ & $8.6 \pm 1.1$ & NA & $0.1 \pm 0$ & $7.3 \pm 0.5$ & NA & $0.2 \pm 0.1$ & $9.0 \pm 0.2$ & NA \\
\hline $\mathrm{TN}$ & $53.5 \pm 18.8$ & $36.8 \pm 13.7$ & $46.8 \pm 4.4$ & $33.3 \pm 1.4$ & $22 \pm 1.3$ & $51.1 \pm 3.4$ & $65.9 \pm 5.9$ & $44.2 \pm 3.9$ & $49 \pm 1.7$ \\
\hline
\end{tabular}

\subsection{Kinetic of Nutrient Removal}

\subsubsection{Kinetic of BOD removal}

The result of linear relationship plotting between $V /\left[Q\left(S_{i}-S_{e}\right)\right]$ and $\mathrm{V} / \mathrm{QS}_{\mathrm{i}}$ for BOD profile derived from the modified StoverKincannon model equation is shown in Fig. 2(a). The high value of correlation coefficient values $\left(R^{2}=0.9928\right)$ indicates a good agreement between the prediction and the experimental data for DHS reactors. Thus, it could be considered that the modified Stover-Kincannon model is capable in describing the performance of the BOD removal used in this study. Kinetic constant $K_{B}$ and $U_{\max }$ were calculated as 75.034 and $56.818 \mathrm{~g} \mathrm{~L}^{-1}$ day ${ }^{-1}$, respectively. Rate expression for the BOD takes the forms below, Eq. (5)

$$
\frac{Q\left(S_{i}-S_{e}\right)}{V}=\frac{56.818\left(Q S_{i} / V\right)}{75.034+\left(Q S_{i} / V\right)}
$$

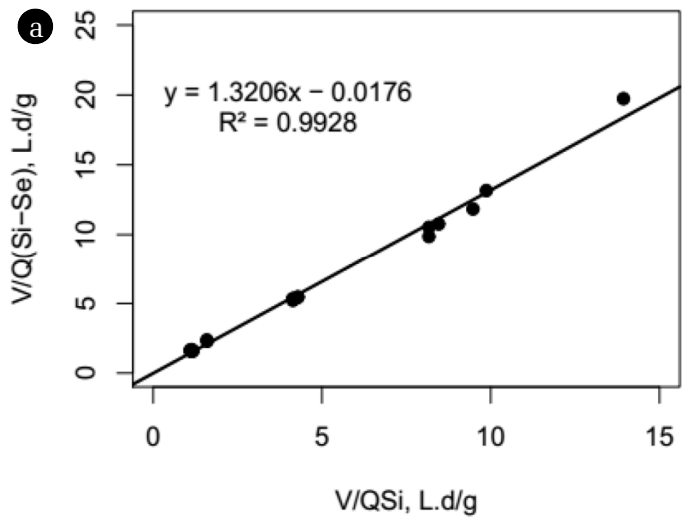

The relationship between predicted and observed effluent BOD concentration in DHS reactor is shown in Fig. 2b. It illustrates that there is a linear relationship between the observed and predicted effluent BOD concentration with $\mathrm{R}^{2}=0.9727$ regression coefficient. Thus, kinetic constants can be used in predicting effluent BOD concentration of DHS reactor. By reforming the Eq. (5), the prediction of effluent BOD concentration is determined by Eq. (5-1), and the prediction of removal efficiency can be given in Eq. (5-2).

$$
\begin{aligned}
& S_{e}=\frac{56.8181 S_{i}}{75.034+\left(Q S_{i} / V\right)} \\
& E=\frac{56.818}{75.034+\left(Q S_{i} / V\right)}
\end{aligned}
$$

According to Eq. (5-2), the predicted result of BOD removal

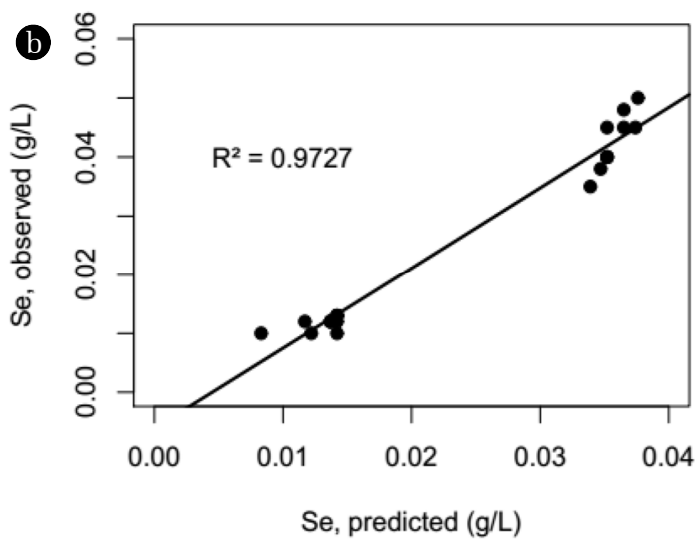

Fig. 2. The kinetic modeling of $\mathrm{BOD}_{5}$ removal. (a) Modified Stover - Kincannon model plot for $\mathrm{BOD}_{5}$ removal, (b) Relationship between observed and predicted effluent $\mathrm{BOD}_{5}$ concentrations. 
by employing Stover-Kincannon model was over 70\%. Comparing the maximum BOD removal from experiment and maximum BOD removal from kinetic models, they are highly correlated. From the previous studied, Faridnasr et al. [19] investigated the kinetic modeling for treatment of sugar-industry wastewater treatment by using a moving-bed biofilm sequencing batch reactor (MBSBR). The result showed that, modified Stover-Kincannon model equation on removal of $\mathrm{BOD}_{5}$ at concentration $500 \mathrm{mg} \mathrm{L}^{-1}$ had $\mathrm{R}^{2}=0.9998$; $\mathrm{U}_{\max }=16.690$ gBOD $_{5} \mathrm{~L}^{-1} \mathrm{~d}^{-1}$ and $\mathrm{K}_{\mathrm{B}}=16.631$ gBOD5 L $^{-1} \mathrm{~d}^{-1}$. Those values of $U_{\max }$ and $K_{B}$ were lower than $U_{\max }$ and $K_{B}$ found in this study indicated that the DHS has an immense potential towards BOD removal. These contradictory results could be due to the effect of different operational conditions and different reactor structures. Several previous studies indicated the results of the modified Stover-Kincannon model application on COD removal. Abyar et al. [17] operated an up-flow anoxic/aerobic sludge bioreactor (UAASB) and achieved the correlation coefficient (R2) as 0.9917 and other kinetic constants as $\mathrm{K}_{\mathrm{B}}=25.997 \mathrm{gCOD} \mathrm{L}^{1}$ $\mathrm{d}^{1}$ and $\mathrm{U}_{\max }=24.75$ gCOD L ${ }^{1} \mathrm{~d}^{1}$. Hassani et al. [37] used a moving bed biofilm reactor (MBBR) treating wastewater containing ethylene glycol, kinetic modeling for removal of COD, the results showed that the modified Stover-Kincannon model was matched with experimental data $\left(\mathrm{R}^{2}=0.9919\right)$, $\mathrm{U}_{\max }$ and $\mathrm{K}_{\mathrm{B}}$ were calculated as $13.62 \mathrm{~g} \mathrm{COD} \mathrm{L}^{1} \mathrm{~d}^{1}$ and $13.14 \mathrm{~g} \mathrm{COD} \mathrm{L}^{1} \mathrm{~d}^{1}$, respectively. Kapdan [20] studied on dyestuff and COD removal of synthetic wastewater. In the result, experimental data was suitable with Modified StoverKincannon model and they found out some kinetic constants for dyestuff and COD were $\mathrm{K}_{\mathrm{B}}=17.8 \mathrm{~g}$ COD L ${ }^{1} \mathrm{~d}^{1}, \mathrm{U}_{\max }=19.5$ g COD L $\mathrm{L}^{1} \mathrm{~d}^{1}$, and $\mathrm{K}_{\mathrm{B}}=37.9$ g COD L $\mathrm{L}^{1} \mathrm{~d}^{1}$, Umax $=12.9$ g COD $\mathrm{L}^{1} \mathrm{~d}^{1}$, respectively. The variance between the mean kinetic constants among researches indicates that reactor configuration and operational conditions can have a great influence on the value of kinetic coefficients. In addition, the relationship between influent/initial concentration and effluent/ equilibrium concentration have been developed by many authors [38, 39]. The other models such as Grau second-order model; Monod model; First order model; Sum-Kinetic model have been applied for kinetic modeling pollutants removal and provided significant results for each case study [29, 40-42].

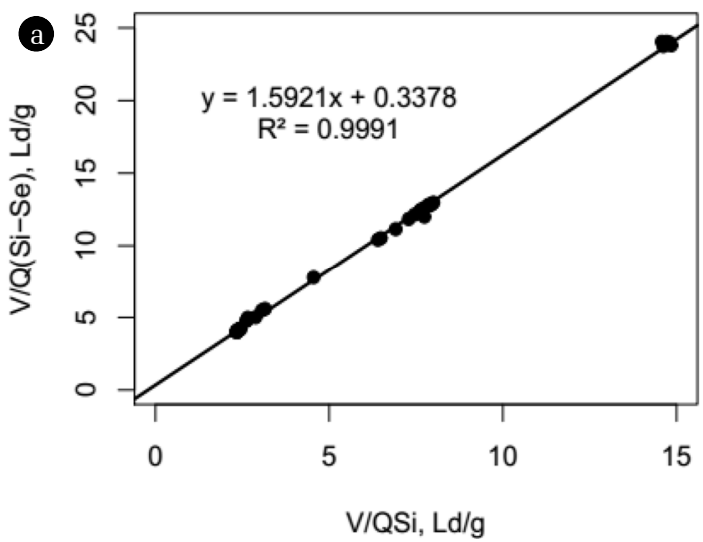

Fig. 3. The kinetic modeling of $\mathrm{NH}_{4}{ }^{+}-\mathrm{N}$ removal. (a) Modified Stover - Kinconnon model plot for $\mathrm{NH}_{4}{ }^{+}-\mathrm{N}$ removal, (b) Relationship between observed and predicted effluent.

\subsubsection{Kinetic of ammonium nitrogen removal}

The application of modified Stover-Kincannon model for simulating of ammonium removal is shown in Fig. 3(a). When $\mathrm{V} /\left[\mathrm{Q}\left(\mathrm{S}_{\mathrm{i}}-\mathrm{S}_{\mathrm{e}}\right)\right]$ is plotted against $\mathrm{V} /(\mathrm{QSi}), \mathrm{K}_{\mathrm{B}} / \mathrm{U}_{\max }$ is the slope and $1 / \mathrm{U}_{\max }$ is the intercept point. From the slope and intercept of Fig. 3(a), kinetic constant $\mathrm{K}_{\mathrm{B}}$ and $\mathrm{U}_{\max }$ values were calculated as $4.713 \mathrm{~g} \mathrm{~L}^{-1}$ day ${ }^{-1}$ and $2.96 \mathrm{~g} \mathrm{~L}^{-1}$ day $^{-1}$, respectively. The correlation coefficient is 0.9991, which considered fairly good precision with the data obtained, confirming the applicability of the modified Stover-Kincannon model. In this study, the saturation constant $\left(\mathrm{K}_{\mathrm{B}}\right)$ and maximum utilization rate $\left(\mathrm{U}_{\max }\right)$ values are larger than those obtained by Yang and colleagues in a Stover-Kincannon model [43]. Abbas et al. [44] investigated partial nitrification and anaerobic ammonia oxidation of synthetic wastewater containing $\mathrm{NH}_{4}{ }^{+}$, they obtained $\mathrm{K}_{\mathrm{B}}=27.253 \mathrm{~g} \mathrm{~L}^{1} \mathrm{~d}^{1}$ and Umax $=22.29$ $\mathrm{g} \mathrm{L}^{1} \mathrm{~d}^{1}\left(\mathrm{R}^{2}=0.9810\right)$ when applied Stover-Kincannon model for collected data [44].

As a result, the rate expression for $\mathrm{NH}_{4}{ }^{+}-\mathrm{N}$ removal takes the following from Eq. (6)

$$
\frac{Q\left(S_{i}-S_{e}\right)}{V}=\frac{2.96\left(Q S_{i} / V\right)}{4.713+\left(Q S_{i} / V\right)}
$$

The relationship between predicted and observed effluent $\mathrm{NH}_{4}{ }^{+}-\mathrm{N}$ concentration in DHS reactor is shown in Fig. 3(b). The Eq. (6) is reformed to calculate the effluent $\mathrm{NH}_{4}{ }^{+}-\mathrm{N}$ concentration in Eq. (6-1). Also, the predicted result of $\mathrm{NH}_{4}{ }^{+}-\mathrm{N}$ removal by employing Stover-Kincannon model was over $57 \%$ according to Eq. (6-2).

$$
\begin{gathered}
S_{e}=S_{i}-\frac{2.961 S_{i}}{4.713+\left(Q S_{i} / V\right)} \\
E=\frac{2.96}{4.713+\left(Q S_{i} / V\right)}
\end{gathered}
$$

Comparing the maximum $\mathrm{NH}_{4}{ }^{+}-\mathrm{N}$ removal from experiment and maximum $\mathrm{NH}_{4}{ }^{+}-\mathrm{N}$ removal from kinetic models, they are similar. This result demonstrates a high correlation between the

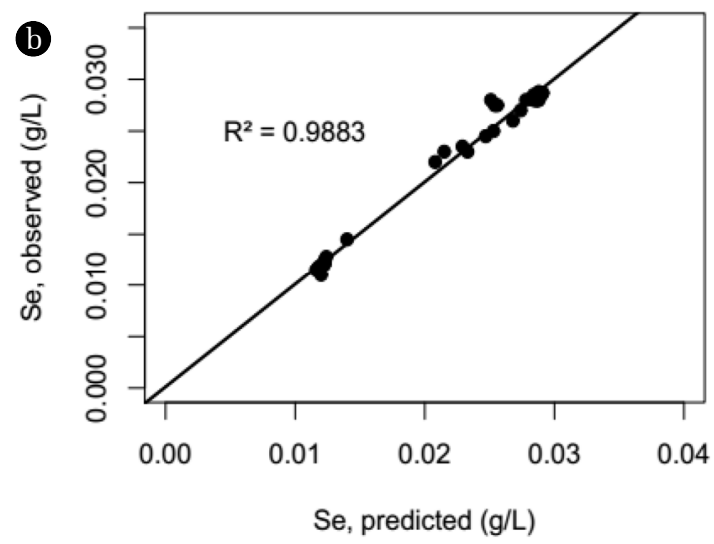

- Kinconnon model plot for $\mathrm{NH}_{4}{ }^{-} \mathrm{N}$ removal, (b) Relationship between 

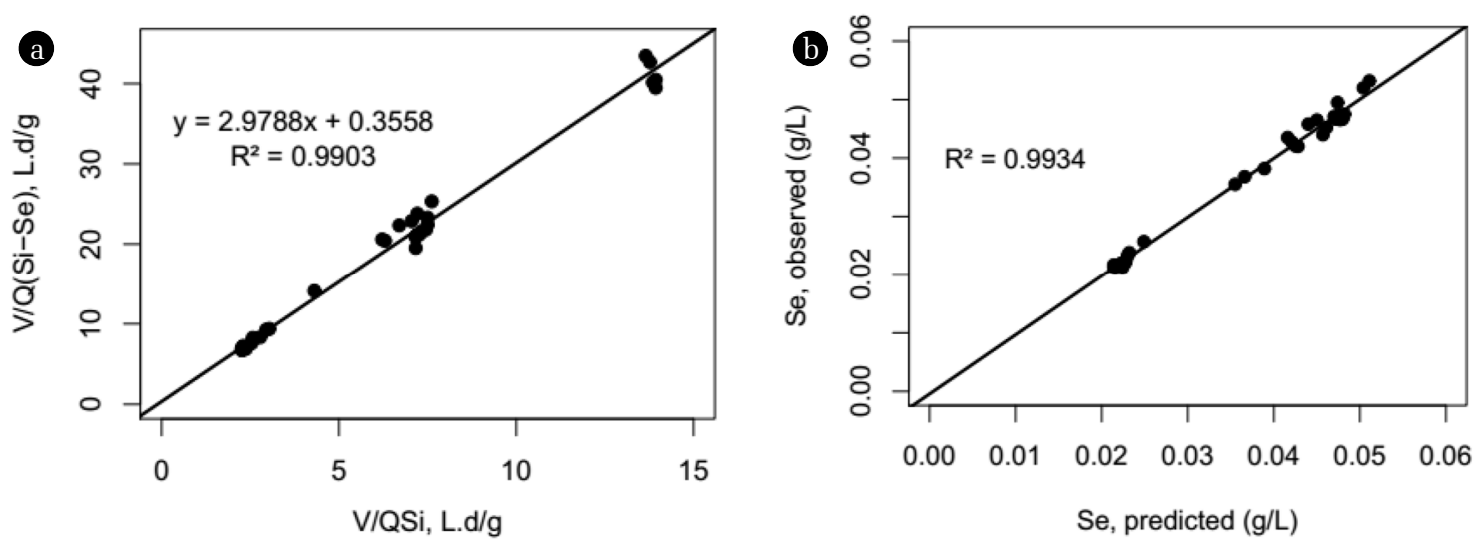

Fig. 4. The kinetic modeling of $\mathrm{NH}_{4}{ }^{+}-\mathrm{N}$ removal. (a) Modified Stover-Kincannon model for TN removal in DHS reactor, (b) Relationship between observed and predicted effluent

actual experimental data and the model data. There have not many publishes described about the using of Stover-Kincannon model for investigation of $\mathrm{NH}_{4}{ }^{+}-\mathrm{N}$ removal in bioreactors.

\subsubsection{Kinetic of total nitrogen removal}

Fig. 4(a) illustrates the straight relationship between $V /\left[Q\left(S_{i}-S_{e}\right)\right]$ and $\mathrm{V} /\left(\mathrm{QS}_{\mathrm{i}}\right)$. The high value of correlation coefficient values $\left(\mathrm{R}^{2}\right.$ $=0.9903$ ) demonstrates a significant experimental result to calculate the value of kinetic constants in order to predict the trend of the treatment system. From this result, the saturation constant $\left(K_{B}\right)$ and the maximum utilization rate $\left(U_{\max }\right)$, the rate constant in modified Stover-Kincannon model, were found to be $8.37 \mathrm{~g} \mathrm{~L}^{-1}$ day $^{-1}$ and $2.81 \mathrm{~g} \mathrm{~L}^{-1}$ day $^{-1}$, respectively. In this study, the $\mathrm{K}_{\mathrm{B}}$ and $\mathrm{U}_{\max }$ values were lower than those published in 2012 by Akhbari and colleagues [45], but the correlation coefficient $\left(R^{2}\right)$ was higher. $\mathrm{Ni}$ et al. [46] applied the modified Stover-Kincannon model to simulate the nitrogen removal process of the UASB. The values of $\mathrm{K}_{\mathrm{B}}$ and $\mathrm{U}_{\max }$ constants were calculated as $12.1 \mathrm{~g} \mathrm{~L}^{1} \mathrm{~d}^{1}$ and 11.4 $\mathrm{g} \mathrm{L}^{1} \mathrm{~d}^{1}$, respectively, with the correlation coefficient is 0.9990. By using this model, Tomar et al. [47] investigated the nitrogen removal by an anammox hybrid reactor, kinetic constant of $U_{\max }$ and $\mathrm{K}_{\mathrm{b}}$ were calculated as 45.045 and $47.072 \mathrm{~g} \mathrm{~L}^{1} \mathrm{~d}^{1}$, respectively. On the other hand, in this study, $K_{B}$ and $U_{\max }$ values were higher than those of Vandith and colleagues [48]. In another study, Modified Stover Kincannon model was applied for kinetic evaluating of UASB-anammox in total nitrogen removal the calculation of $\mathrm{U}_{\max }$ and $\mathrm{K}_{\mathrm{B}}$ were like 3.33 and 4.03, $\mathrm{g} \mathrm{L}^{1} \mathrm{~d}^{1}$, respectively [49]. This implies that the hybrid reactor configuration has animmense potential towards nitrogen removal. The relationship between predicted and observed effluent TN concentration in DHS reactor is shown in Fig. 4(b). The effluent TN concentration can then be predicted by using Eq. (7). Furthermore, the modified Stover-Kincannon model was developed to predict the efficiency of TN removal. The formula is given in Eq. (8)

$$
\begin{gathered}
S_{e}=S_{i}-\frac{2.81 S_{i}}{8.37+\left(Q S_{i} / V\right)} \\
E=\frac{2.81}{8.37+\left(Q S_{i} / V\right)}
\end{gathered}
$$

\section{Conclusions}

In the present research, a down-flow hanging sponge bioreactor was operated for the treatment of domestic wastewater. The reactor was performed stably during the experimental duration. The kinetic modeling of $\mathrm{BOD}_{5} ; \mathrm{NH}_{4}{ }^{+}-\mathrm{N}$; and $\mathrm{TN}$ removal was investigated by using Stover-Kincannon model. The results of this study demonstrated that the Stover-Kincannon model fits well for estimating of kinetic coefficients indicated at a high value of the coefficient of determination. From these coefficients, the prediction of removal efficiency was $70 \%$ for $\mathrm{BOD}_{5} ; 57 \%$ for $\mathrm{NH}_{4}{ }^{+}-\mathrm{N}$ and $33 \%$ for TN. In conclusion, it is suitable to undertake a nonlinear regression technique using of kinetic coefficients of Stover-Kincannon model for predicting the performance of down-flow hanging sponge bioreactor.

\section{Acknowledgments}

The authors would like to express their sincerest thanks to Vietnam Ministry of Natural resource and Environment for financial support; Ho Chi Minh City University of Natural resource and Environment, Nong Lam University - Ho Chi Minh City for accommodation the experimental facilities.

\section{References}

1. Zhou Z, Shen X, Jiang LM, et al. Modeling of multimode anaerobic/anoxic/aerobic wastewater treatment process at low temperature for process optimization. Chem. Eng. J. 2015;281:644-650.

2. Saleh TA, Tuzen M, Sarı A. Magnetic activated carbon loaded with tungsten oxide nanoparticles for aluminum removal from waters. J. Environ. Chem. Eng. 2017;5: 2853-2860.

3. Saleh TA, Tuzen M, Sari A. Polyamide magnetic palygorskite for the simultaneous removal of $\mathrm{Hg}(\mathrm{II})$ and methyl mercury; with factorial design analysis. J. Environ. Manage. 2018;211: 323-333. 
4. Tuzen M, Sari A, Saleh TA. Response surface optimization, kinetic and thermodynamic studies for effective removal of rhodamine B by magnetic $\mathrm{AC} / \mathrm{C}_{\mathrm{e}} \mathrm{O}_{2}$ nanocomposite. J. Environ. Manage. 2018;206:170-177.

5. Saleh TA. Mercury sorption by silica/carbon nanotubes and silica/activated carbon: A comparison study. Aqua 2015;64:892-903.

6. Saleh TA. Isotherm, kinetic, and thermodynamic studies on $\mathrm{Hg}(\mathrm{II})$ adsorption from aqueous solution by silica- multiwall carbon nanotubes. Environ. Sci. Pollut. Res. Int. 2015;22: 16721-16731.

7. Saleh TA, Adio SO, Asif M, Dafalla H. Statistical analysis of phenols adsorption on diethylenetriamine-modified activated carbon. J. Clean. Prod. 2018;182:960-968.

8. Javid A, Hassani A, Ghanbari B, Yaghmaeian K. Feasibility of utilizing moving bed biofilm reactor to upgrade and retrofit municipal wastewater treatment plants. Int. J. Environ. Res. 2013;7:963-972.

9. Metcalf E, Eddy M. Wastewater engineering: Treatment and resource recovery. Vol. 5. New York: Mic Graw-Hill; 2014.

10. Machdar I, Sekiguchi Y, Sumino H, Ohashi A, Harada H. Combination of a UASB reactor and a curtain type DHS (downflow hanging sponge) reactor as a cost-effective sewage treatment system for developing countries. Water Sci. Technol. 2000;42:83-88

11. Mahmoud M, Tawfik A, El-Gohary F. Use of down-flow hanging sponge (DHS) reactor as a promising post-treatment system for municipal wastewater. Chem. Eng. J. 2011;168:535-543.

12. Tandukar M, Ohashi A, Harada H. Performance comparison of a pilot-scale UASB and DHS system and activated sludge process for the treatment of municipal wastewater. Water Res. 2007;41:2697-2705.

13. Tawfik A, El-Gohary F, Ohashi A, Harada H. The influence of physical-chemical and biological factors on the removal of faecal coliform through down-flow hanging sponge (DHS) system treating UASB reactor effluent. Water Res. 2006;40:1877-1883.

14. Fleifle A, Tawfik A, Saavedra OC, Elzeir M. Treatment of agricultural drainage water via downflow hanging sponge system for reuse in agriculture. Water Supply 2013;13:403-412.

15. Nomoto N, Ali M, Jayaswal K, et al. Characteristics of DO, organic matter, and ammonium profile for practical-scale DHS reactor under various organic load and temperature conditions. Environ. Technol. 2018;39:907-916.

16. Yoochatchaval W, Onodera T, Sumino H, et al. Development of a down-flow hanging sponge reactor for the treatment of low strength sewage. Water Sci. Technol. 2014;70:656-663.

17. Abyar H, Younesi H, Bahramifar N, Zinatizadeh AA, Amini $\mathrm{M}$. Kinetic evaluation and process analysis of COD and nitrogen removal in UAASB bioreactor. J. Taiwan Instit. Chem. Eng. 2017;78:272-281.

18. Debik E, Coskun T. Use of the Static Granular Bed Reactor (SGBR) with anaerobic sludge to treat poultry slaughterhouse wastewater and kinetic modeling. Bioresour. Technol. 2009;100:2777-2782.

19. Faridnasr M, Ghanbari B, Sassani A. Optimization of the moving-bed biofilm sequencing batch reactor (MBSBR) to control aeration time by kinetic computational modeling: simulated sugar-industry wastewater treatment. Bioresour. Technol. 2016;208:149-160.

20. Kapdan IK. Kinetic analysis of dyestuff and COD removal from synthetic wastewater in an anaerobic packed column reactor. Process Biochem. 2005;40:2545-2550.

21. Diamantis V, Aivasidis A. Kinetic analysis and simulation of UASB anaerobic treatment of a synthetic fruit wastewater. Global NEST J. 2010;12:175-180.

22. Vital-Jacome M, Buitrón G, Moreno-Andrade I, Garcia-Rea V, Thalasso F. Microrespirometric determination of the effectiveness factor and biodegradation kinetics of aerobic granules degrading 4-chlorophenol as the sole carbon source. J. Hazard. Mater. 2016;313:112-121.

23. Hu Z-H, Yu H-Q, Yue Z-B, Harada H, Li Y-Y. Kinetic analysis of anaerobic digestion of cattail by rumen microbes in a modified UASB reactor. Biochem. Eng. J. 2007;37:219-225.

24. Bhunia P, Ghangrekar M. Analysis, evaluation, and optimization of kinetic parameters for performance appraisal and design of UASB reactors. Bioresour. Technol. 2008;99:2132-2140.

25. Frascari D, Zanaroli G, Bucchi G, et al. Trichloroethylene aerobic cometabolism by suspended and immobilized butane-growing microbial consortia: A kinetic study. Bioresour. Technol. 2013;144:529-538.

26. Hussain A, Dubey SK, Kumar V. Kinetic study for aerobic treatment of phenolic wastewater. Water Resour. Ind. 2015;11:81-90.

27. Karkare M, Murthy Z. Kinetic studies on agrochemicals wastewater treatment by aerobic activated sludge process at high MLSS and high speed agitation. J. Ind. Eng. Chem. 2012;18:1301-1307.

28. Lim J, Vadivelu V. Treatment of agro based industrial wastewater in sequencing batch reactor: Performance evaluation and growth kinetics of aerobic biomass. J. Environ. Manage. 2014;146:217-225.

29. Tamrat M, Costa C, Márquez MC. Biological treatment of leachate from solid wastes: Kinetic study and simulation. Biochem. Eng. J. 2012;66:46-51.

30. Kincannon DF, Stover EL. Design methodology for fixed film reaction-RBCs and biological towers. In: Civil engineering for practicing and design engineers. New York: Pergamon Press; 1982.

31. Yu H, Wilson F, Tay JH. Kinetic analysis of an anaerobic filter treating soybean wastewater. Water Res. 1998;32:3341-3352.

32. Hiep NT, Tuyet LTH, Nga DT, Tuan PD. A research on the performance of down-flow hanging sponge (DHS) reactor treating domestic wastewater. Vietnam J. Sci. Technol. 2018;56:482-492.

33. APHA. Standard Methods for the Examination of Water and Wastewater. 21st ed. American Public Health Association/ American Water Works Association/Water Environment Federation. Washington D.C; 2005. p. 75.

34. Aqualytic. Determining Biochemical Oxygen Demand (BOD). Deutsches Institut für Normung e.V.; 1994; Berlin.

35. Alighardashi A, Modanlou M, Shervin J. Performance evaluation of anaerobic baffled reactor (ABR) treating pulp and paper wastewater in start-up period. Water Prac. Technol. 2015;10:1-9.

36. Yang GF, Feng LJ, Wang SF, Yang Q, Xu XY, Zhu L. Performance 
and enhanced mechanism of a novel bio-diatomite biofilm pretreatment process treating polluted raw water. Bioresour. Technol. 2015;191:271-280.

37. Hassani AH, Borghei SM, Samadyar H, Ghanbari B. Utilization of moving bed biofilm reactor for industrial wastewater treatment containing ethylene glycol: Kinetic and performance study. Environ. Technol. 2014;35:499-507.

38. Saleh TA. Nanocomposite of carbon nanotubes/silica nanoparticles and their use for adsorption of $\mathrm{Pb}(\mathrm{II})$ : From surface properties to sorption mechanism. Desal. Water Treat. 2015;57:10730-10744.

39. Saleh TA. Simultaneous adsorptive desulfurization of diesel fuel over bimetallic nanoparticles loaded on activated carbon. J. Clean. Prod. 2018;172:2123-2132.

40. Amin MM, Khiadani MH, Fatehizadeh A, Taheri E. Validation of linear and non-linear kinetic modeling of saline wastewater treatment by sequencing batch reactor with adapted and non-adapted consortiums. Desalination 2014;344:228-235.

41. Dey S, Mukherjee S. Kinetic modeling and factorial design for co-biodegradation of phenol and m-cresol for aerobic batch reactor system. Mater. Today Proc. 2016;3:3450-3460.

42. Carboneras B, Villasenor J, Fernandez-Morales FJ. Modelling aerobic biodegradation of atrazine and 2,4-dichlorophenoxy acetic acid by mixed-cultures. Bioresour. Technol. 2017;243: 1044-1050.

43. Yang G, Feng L, Wang S, et al. Potential risk and control strategy of biofilm pretreatment process treating raw water. Bioresour. Technol. 2015;198:456-463.

44. Abbas G, Wang L, Li W, Zhang M, Zheng P. Kinetics of nitrogen removal in pilot-scale internal-loop airlift bio-particle reactor for simultaneous partial nitrification and anaerobic ammonia oxidation. Ecol. Eng. 2015;74:356-363.

45. Akhbari A, Zinatizadeh A, Mohammadi P, Mansouri Y, Irandoust $\mathrm{M}$, Isa $\mathrm{M}$. Kinetic modeling of carbon and nutrients removal in an integrated rotating biological contactor-activated sludge system. Int. J. Environ. Sci. Technol. 2012;9:371-378.

46. Ni S-Q, Sung S, Yue Q-Y, Gao B-Y. Substrate removal evaluation of granular anammox process in a pilot-scale upflow anaerobic sludge blanket reactor. Ecol. Eng. 2012;38:30-36.

47. Tomar S, Gupta SK. Investigating the role of co-substrate-substrate ratio and filter media on the performance of anammox hybrid reactor treating nitrogen rich wastewater. J. Biosci. Bioenerg. 2016;121:310-316.

48. Vandith V, Setiyawan A S, Soewondo P, Bophann P. Kinetics of nutrient removal in an on-site domestic wastewater treatment facility. In: MATEC Web of Conferences; 22 January 2018; 04004

49. Niu Q, Zhang Y, Ma H, He S, Li YY. Reactor kinetics evaluation and performance investigation of a long-term operated UASB-anammox mixed culture process. Int. Biodeterior. Biodegrad. 2016;108:24-33. 